\title{
The effect of taxifolin on high-dose-cisplatin- induced oxidative liver injury in rats
}

\author{
Nezahat Kurt ${ }^{1, A, C, D}$, Özge Nur Türkeri' ${ }^{2, B}$, Bahadir Suleyman ${ }^{3, B, C}$, Nuri Bakan $^{4, F}$ \\ ${ }^{1}$ Department of Medical Biochemistry, Faculty of Medicine, Erzincan Binali Y.ldırım University, Turkey \\ ${ }^{2}$ Department of Nutrition and Dietetics, Faculty of Health Sciences, European University of Lefke, Cyprus \\ ${ }^{3}$ Department of Pharmacology, Faculty of Medicine, Erzincan Binali Yıldırım University, Turkey \\ ${ }^{4}$ Department of Medical Biochemistry, Faculty of Medicine, Atatürk University, Erzurum, Turkey \\ A - research concept and design; $\mathrm{B}$ - collection and/or assembly of data; $\mathrm{C}$ - data analysis and interpretation; \\ $\mathrm{D}$ - writing the article; $\mathrm{E}$ - critical revision of the article; $\mathrm{F}$ - final approval of the article
}

\section{Address for correspondence \\ Nezahat Kurt}

E-mail: nezahat.kurt@erzincan.edu.tr

\section{Funding sources}

None declared

Conflict of interest

None declared

Received on 0ctober 28, 2020

Reviewed on March 22, 2021

Accepted on May 31, 2021

Published online on August 24, 2021

\begin{abstract}
Background. Cisplatin is a non-specific platinum-based (derivative) chemotherapeutic agent that causes an increase in free radicals activity in the liver. Antioxidant activity of taxifolin has been demonstrated previously, and it has been reported that taxifolin inhibits the hydroxyl, radical in experimental studies.

Objectives. No studies were found in the current literature examining the protective effect of taxifolin on cisplatin-induced oxidative liver damage. We aimed to determine the protective effect of taxifolin on cisplatin-induced hepatotoxicity in an experimental study.

Materials and methods. In total, 18 albino Wistar male rats were assigned into 3 groups: healthy controls (HC group), $5 \mathrm{mg} / \mathrm{kg}$ of cisplatin administered for 8 days (CIS group) and $50 \mathrm{mg} / \mathrm{kg}$ of taxifolin $+5 \mathrm{mg} / \mathrm{kg}$ of cisplatin administered for 8 days (TCG group). Malondialdehyde (MDA), total glutathione (tGSH), total oxidant (TOS), and total antioxidant (TAS) capacity levels were measured in the extracted liver tissue.
\end{abstract}

Results. Liver tissue MDA and TOS levels were significantly higher in the CIS group. In contrast, $\mathrm{CGSH}$ and TAS levels were significantly lower in the CIS group, administered cisplatin alone $(p<0.001)$, compared to other groups. In the TCG group, administered cisplatin + taxifolin, MDA and TOS levels were significantly lower, whereas tGSH and TAS levels were significantly higher than in the CIS group ( $p<0.001)$.

Conclusions. These results suggest that taxifolin may be useful in preventing cisplatin-related liver injury.

Key words: cancer, hepatotoxicity, cisplatin, taxifolin, antioxidant

Cite as

Kurt N, Türkeri ÖN, Suleyman B, Bakan N. The effect of taxifolin on high-dose-cisplatin-induced oxidative liver injury in rats. Adv Clin Exp Med. 2021;30(10):1025-1030. doi:10.17219/acem/138318

DOI

10.17219/acem/138318

Copyright

Copyright by Author(s)

This is an article distributed under the terms of the

Creative Commons Attribution 3.0 Unported (CC BY 3.0)

(https://creativecommons.org/licenses/by/3.0/) 


\section{Background}

Cisplatin is a non-specific platinum-based (derivative) chemotherapeutic agent used to treat stomach, testis, ovarian, bladder, kidney, ureterovesical, head, and neck cancer. ${ }^{1}$ It has been reported to cause serious toxic effects in many organs and systems during treatment. ${ }^{2-4}$ The chemotherapeutic efficacy of cisplatin increases together with the dose. However, the increase in dose causes side effects such as nephrotoxicity, ototoxicity, neurotoxicity, hepatotoxicity, nausea, vomiting and, in $67 \%$ of patients, diarrhea, limiting its clinical use. ${ }^{5,6}$ Cisplatin also causes an increase in free radicals activity in the liver, leading to oxidative stress. ${ }^{7}$ Intravenously administered cisplatin $\left(180-480 \mathrm{mg} / \mathrm{m}^{2}\right)$ can also reach high concentrations in the liver, except in kidney and intestine, and may cause significant toxicity. ${ }^{8}$ Therefore, it has been reported that the most critical side effects are hepatotoxicity and nephrotoxicity. ${ }^{9}$ Hepatotoxicity manifests as an increase in serum transaminase (alanine aminotransferase (ALT) and aspartate aminotransferase (AST)) levels. Even the treatment dose used as a tumor suppressor has been shown to cause hepatotoxicity. ${ }^{10}$ Although the mechanism of injury of cisplatin is not well known, some evidence suggests that it is caused by oxidative stress, due to reactive oxygen species (ROS) activity. ${ }^{7}$ The oxidative stress induced by ROS causes a decrease in glutathione (GSH), which is an endogenous antioxidant.

Furthermore, ROS affect cell membrane lipid peroxidation and lead to occurrence of more toxic products such as malondialdehyde (MDA). ${ }^{11}$ This suggests that antioxidant therapy may help to prevent or reduce cisplatininduced hepatotoxicity. Studies have shown that various antioxidants are protective against cisplatin hepatotoxicity. ${ }^{12}$ However, hepatotoxicity caused by cisplatin remains one of the crucial reasons for limiting its use at the desired dose. Therefore, several kinds of research to alleviate cisplatin hepatotoxicity are being pursued. In our study, we investigated whether taxifolin $(3,3$, ,', 5,7 -pentahydroxiflavanone), a flavonoid contained in onions, milk thistle, French maritime bark, and Douglas fir bark, has a protective effect against the hepatotoxicity of cisplatin. ${ }^{13}$ Antioxidant activity of taxifolin has been documented. ${ }^{14}$ In experimental studies, taxifolin has been reported to inhibit the hydroxyl radical $(\bullet \mathrm{OH})$, a ROS in the cell, and protects cellular DNA from oxidative damage by antioxidant activity. ${ }^{15}$ These data suggest that taxifolin will protect liver tissue against the oxidative damage caused by cisplatin.

\section{Objectives}

No data were found in literature reviews regarding the protective effects of taxifolin on cisplatin-induced liver toxicity. Therefore, our study aimed to investigate, through biochemical analysis, whether or not taxifolin has a protective effect on cisplatin-induced hepatotoxicity in rats.

\section{Materials and methods}

\section{Study animals}

Eighteen albino Wistar male rats (255-266 g) were obtained from Atatürk University Medical Experimental Application and Research Center (Erzurum, Turkey). Before the experiment, animals were housed and fed in the laboratory for 1 week at normal room temperature $\left(22^{\circ} \mathrm{C}\right)$. Animal experiments were performed according to the National Guidelines for the Use and Care of Laboratory Animals and were approved by the local animal ethics committee of Atatürk University (approval No. 75296309-050.01.04E.1800138920, May 4, 2018).

\section{Experimental procedure}

The experimental animals were divided into healthy control (HC) group, $5 \mathrm{mg} / \mathrm{kg}$ of cisplatin (CIS) group and $50 \mathrm{mg} / \mathrm{kg}$ of taxifolin $+5 \mathrm{mg} / \mathrm{kg}$ of cisplatin (TCG) group. In this experiment, $50 \mathrm{mg} / \mathrm{kg}$ of taxifolin (Evalar, Biysk, Russia) was administered to the rats in the TCG group $(n=6)$ via oral gavage. In the CIS $(n=6)$ and $\mathrm{HC}(n=6)$ groups, distilled water as a solvent was administered orally. In the literature, the drugs investigated for action against the toxicity of cisplatin were generally administered to the experimental animals $1 \mathrm{~h}$ before cisplatin. ${ }^{16}$ One hour after the administration of taxifolin and distilled water, a total of 4 doses of cisplatin (Ebewe-Liba, Istanbul, Turkey) were injected into animals from TCG and CIS groups at a dose of $5 \mathrm{mg} / \mathrm{kg}$ intraperitoneally (ip.) every 2 days. ${ }^{17}$ Taxifolin and distilled water were administered with the same method for 8 days once a day in the specified dose and volume. At the end of this period, the animals were sacrificed with high-dose $(50 \mathrm{mg} / \mathrm{kg})$ thiopental (IE Ulagay, Istanbul, Turkey) anesthesia, and the liver tissues were removed. Malondialdehyde, tGSH, total oxidant status (TOS), and total antioxidant status (TAS) levels were measured in the extracted liver tissue. In addition, blood samples were collected from the lateral tail vein of nonanesthetized rats and centrifuged at $1500 \times \mathrm{g}$ for $10 \mathrm{~min}$. Then, ALT and AST activity was measured in the serum.

\section{Biochemical analyses}

Before dissection, all tissues were rinsed with phosphatebuffered saline solution. The liver tissues were homogenized in ice-cold phosphate buffers $(50 \mathrm{mM}, \mathrm{pH} 7.4)$ that were appropriate for the variable to be measured. The tissue homogenates were centrifuged at $5000 \mathrm{rpm}$ for $20 \mathrm{~min}$ at $4^{\circ} \mathrm{C}$, and the supernatants were extracted to analyze MDA, tGSH, TAS, TOS, and protein concentration. The protein concentration of the supernatant was measured using the method described by Bradford. All tissue results were expressed by dividing by grams of protein. ${ }^{18}$ All spectrophotometric measurements were performed using a microplate reader (BioTek ${ }^{\circledR}$ Powerwave XS ${ }^{\mathrm{TM}}$; BioTek ${ }^{\circledR}$, Winooski, USA). 


\section{Malondialdehyde analysis}

Malondialdehyde measurements were based on the method used by Ohkawa et al., involving spectrophotometrically measured absorbance of the pink-colored complex formed by thiobarbituric acid (TBA) and MDA. Briefly, $25 \mu \mathrm{L}$ of tissue homogenate was added to a solution containing $25 \mu \mathrm{L}$ of $80 \mathrm{~g} / \mathrm{L}$ sodium dodecyl sulfate and $1 \mathrm{~mL}$ of mixture solution $(20 \mathrm{~g} / \mathrm{L}$ of acetic acid $+1.06 \mathrm{~g} 2$-thiobarbiturate $+180 \mathrm{~mL}$ of distilled water). The mixture was incubated at $95^{\circ} \mathrm{C}$ for $1 \mathrm{~h}$. Upon cooling, the mixture was centrifuged for $10 \mathrm{~min}$ at $4000 \mathrm{rpm}$. The absorbance of the supernatant was measured at $532 \mathrm{~nm}$. The standard curve was obtained by using 1,1,3,3-tetramethoxypropane. ${ }^{19}$

\section{Total glutathione (GSH) analysis}

The amount of GSH in the total homogenate was measured with the method used by Sedlak et al. ${ }^{20}$ and Baker et al., ${ }^{21}$ with some modifications. The principle of the method is that the color intensity of dark yellow 5-thio-2-nitrobenzoic acid (TNB). The TNB is released through the reduction of Ellman's reagent $\left(5,5^{\prime}\right.$-dithiobis (2-nitrobenzoicacid) - DTNB) by free thiol groups, and is measured at a $412 \mathrm{~nm}$ wavelength $(2 \mathrm{GSH}+\mathrm{DTNB} \rightarrow$ G-S-S-G + 2 TNB, dark yellow color compound).

First, the deproteinization process was applied to all homogenate samples to eliminate the reaction of protein sulfhydryl groups with Ellman's reagent. The tissue homogenate was precipitated with $200 \mu \mathrm{L}$ of $25 \%$ trichloroacetic acid, and the precipitate was removed after centrifugation at $2500 \times \mathrm{g}$ for $5 \mathrm{~min}$ at $4^{\circ} \mathrm{C}$. The obtained supernatant was used to determine the GSH level. A total of $200 \mu \mathrm{L}$ of measurement buffer $(200 \mathrm{mmol} / \mathrm{L}$ of Tris- $\mathrm{HCl}$ buffer containing $0.2 \mathrm{mmol} / \mathrm{L}$ of ethylenediaminetetraacetic acid (EDTA) at pH 8.9), $100 \mu \mathrm{L}$ of supernatant, $5 \mu \mathrm{L}$ of DTNB $(10 \mathrm{mmol} / \mathrm{L}$ in methanol), and $5 \mu \mathrm{L}$ glutathione reductase-NADPH mix (3.75 mL of $1 \mathrm{mM}$ NADPH, and $80 \mu \mathrm{L}$ of $625 \mathrm{U} / \mathrm{L}$ glutathione reductase) were added to the plate and incubated for $5 \mathrm{~min}$ at room temperature. The DTNB was used as a chromogen, and it formed a yellow-colored complex with sulfhydryl groups. The absorbance was measured at $412 \mathrm{~nm}$ using a spectrophotometer mentioned above. The standard curve was obtained using reduced GSH. According to the GSH standard curve, the GSH levels of all tissues are calculated, and the results are expressed as nmol GSH/mg protein.

\section{Total antioxidant status (TAS) and total oxidative status (TOS) analyses}

The TOS and TAS levels of tissue homogenates were determined using a novel automated measurement method and commercially available kits (Rel Assay Diagnostics, Gaziantep, Turkey), both developed by Erel. ${ }^{22,23}$ The TAS method is based on bleaching the characteristic color of a more stable ABTS (2,2'-azino-bis (3-ethylbenzothiazoline-6-sulfonic acid)) radical cation by antioxidants, and measurements are performed at $660 \mathrm{~nm}$. The results are expressed as nmol Trolox equivalent/L. In the TOS method, the oxidants present in the sample oxidized the ferrous ion-o-dianisidine complex to ferric ion. The oxidation reaction was enhanced by glycerol molecules, which are abundantly present in the reaction medium. The ferric ion produced a colored complex with xylenol orange in an acidic medium. The color intensity, which could be measured at $530 \mathrm{~nm}$ spectrophotometrically, was related to the total amount of oxidant molecules present in the sample. The results are expressed as nmol hydrogen peroxide $\left(\mathrm{H}_{2} \mathrm{O}_{2}\right)$ equivalent/L.

\section{ALT and AST analysis}

Serum ALT and AST analysis were performed on a Roche Cobas 8000 autoanalyzer using the spectrophotometric method and kits from the same company (REF: 207649557322, 20764949-322, respectively; Roche Diagnostics, Basel, Switzerland). The principle of both measurements is based on measuring the absorbance change of NADH at $340 \mathrm{~nm}$.

\section{Statistical analyses}

Statistical analyses were performed using IBM SPSS software v. 21.0 (IBM Corp., Armonk, USA). The estimated power (1-beta) test value was calculated as 0.99 with the G-Power Program (https://www.psychologie.hhu.de/arbeitsgruppen/allgemeine-psychologie-und-arbeitspsychologie/gpower). Numerical variables were expressed as a median (min-max). For the analysis of continuous variables, the Kruskal-Wallis test was performed. For between 2 groups, Dunn's test (a post hoc comparison test) was performed. The minimum criterion for statistical significance was set at $\mathrm{p}<0.05$ for all comparisons.

\section{Results}

As shown in Table 1, serum ALT and AST activity were significantly higher in the CIS group compared with the HC and TCG groups ( $\mathrm{p}<0.001)$.

When mean MDA levels were compared, statistically significant differences were found between the study groups ( $\mathrm{p}<0.05)$. The amount of MDA in the TCG group was significantly decreased compared to the CIS group ( $\mathrm{p}<0.001$ ), but no significant difference was found compared to the HC group ( $\mathrm{p}>0.05)$. When the mean tGSH levels were compared in the study groups, there was a statistically significant difference among the groups ( $\mathrm{p}<0.05)$. In the TCG group, tGSH levels were significantly higher ( $\mathrm{p}<0.001$ ) compared to the CIS and HC groups (Table 1).

There was a statistically significant difference among the groups in terms of TOS levels $(p<0.05)$. The levels 
Table 1. The results of biochemical evaluations among groups

\begin{tabular}{|c|c|c|c|c|}
\hline \multirow[b]{2}{*}{ Variables } & \multicolumn{4}{|c|}{ Groups } \\
\hline & $\begin{array}{c}\text { CIS } \\
\text { median (min-max) } \\
(n=6)\end{array}$ & $\begin{array}{c}\text { TCG } \\
\text { median (min-max) } \\
(n=6)\end{array}$ & $\begin{array}{c}\mathrm{HC} \\
\text { median (min-max) } \\
(\mathrm{n}=6)\end{array}$ & $p$-value \\
\hline MDA [ $\mu \mathrm{mol} / \mathrm{g}$ protein] & $8.65(7.9-9.1)^{b, c}$ & $2.50(2.2-3.7)^{\mathrm{a}}$ & $3.05(2.8-3.9)^{\mathrm{a}}$ & 0.002 \\
\hline tGSH [nmol/g protein] & $1.65(1.4-2.1)^{b, c}$ & $4.85(4.2-5.1)^{\mathrm{a}}$ & $5.45(5.1-5.7)^{\mathrm{a}}$ & 0.001 \\
\hline TAS [nmol Trolox eq/mg protein] & $5.45(4.7-6.1)^{b, c}$ & $12.00(10.0-16.0)^{\mathrm{a}}$ & $14.50(12.0-17.0)^{\mathrm{a}}$ & 0.002 \\
\hline $\mathrm{TOS}$ [nmol $\mathrm{H}_{2} \mathrm{O}_{2}$ eq/mg protein] & $18.00(15.0-21.0)^{b, c}$ & $7.00(6.1-8.0)^{\mathrm{a}}$ & $6.25(5.1-7.1)^{\mathrm{a}}$ & 0.001 \\
\hline AST [IU/L] & $200.06(178.5-235.4)^{b, c}$ & $48.71(38.1-56.3)^{\mathrm{a}}$ & $40.43(34.7-48.8)^{a}$ & 0.001 \\
\hline $\mathrm{ALT}[\mathrm{IU} / \mathrm{L}]$ & $100.12(89.2-116.8)^{b, c}$ & $38.07(34.5-41.4)^{a}$ & $30.66(23.6-34.5)^{a}$ & 0.001 \\
\hline
\end{tabular}

$\mathrm{HC}$ - healthy control; CIS - 5 mg/kg cisplatin group; TCG - 50 mg/kg taxifolin + 5 mg/kg cisplatin group; MDA - malondialdehyde; tGSH - total glutathione; TAS - total antioxidant status; TOS - total oxidative status; ALT - alanine aminotransferase; AST - aspartate aminotransferase.

a - statistically significantly different compared with $\mathrm{CIS}_{i}{ }^{\mathrm{b}}$ - statistically significantly different compared with $\mathrm{TCG}{ }^{{ }^{c}}-$ statistically significantly different compared with $\mathrm{HC}$

of TOS in the liver tissue of the TCG group were significantly lower compared to the CIS group $(\mathrm{p}<0.001)$. There was no significant difference between the TCG and HC groups in terms of TOS level ( $p>0.05)$. When the mean TAS levels were compared in the study groups, statistically significant differences were found $(\mathrm{p}<0.05)$. The level of TAS in the liver tissue of the TCG group was significantly higher compared to the CIS group ( $<<0.05$ ) (Table 1). However, the difference between TAS levels in TCG and $\mathrm{HC}$ groups was insignificant $(\mathrm{p}>0.05)$ (Table 1$)$.

\section{Discussion}

In our study, the effect of taxifolin on cisplatin-induced oxidative liver injury in rats was investigated biochemically. There are many studies showing cisplatin-induced liver damage. ${ }^{7,24}$ In our research, in parallel with the literature, serum ALT and AST levels increased after exposure to high doses of cisplatin. These values decreased after administration of taxifolin. Our results showed that cisplatin caused an increase in MDA and TOS levels and a decrease of tGSH and TAS levels in animal liver tissue. Oxidantantioxidant parameters are used to determine oxidative tissue damage ${ }^{25}$ and evaluate the biochemical toxicity of drugs. ${ }^{26}$ Increased MDA production in the CIS group suggests that lipid peroxidation is exacerbated in liver tissue cells in this group. The ROS lead to the peroxidation of lipids in the cell membrane and result in the secretion of more toxic products, such as MDA, from lipids. ${ }^{11}$ Malondialdehyde can cause damage in membrane proteins by inactivating receptors and membrane-bound enzymes in membranes, leading to cross-linking and polymerization of membrane components. ${ }^{27}$ The LPO reaction is either terminated by scavenging antioxidant reactions or continues with auto-catalytic spreading reactions. ${ }^{28}$ Studies have suggested that ROS also play a role in the pathogenesis of the hepatotoxic effect of cisplatin. ${ }^{7}$ Niu et al. reported that the amount of MDA increased in cisplatin-associated liver oxidative damage. ${ }^{29}$ In our study, high TOS values measured after cisplatin administration indicate cisplatin-induced oxidative stress. The level of TOS was found to be increased in the CIS group, where MDA level was high. The TOS is used to determine the cumulative oxidative effects of various oxidants in biological systems. ${ }^{23}$ Studies have shown that cisplatin elevates TOS levels not only in the liver tissue but also in the kidney tissue. ${ }^{30}$ This is consistent with our experimental results showing that MDA and TOS levels in liver tissue were increased.

Again, in this study, it was observed that cisplatin decreased the amount of tGSH in liver tissue compared to the TCG and the HC group. To prevent the harmful effects of ROS, living organisms develop several effective protection mechanisms both in the cell and in the cell membrane. These mechanisms act both by blocking radical production and by eliminating the harmful effects of the radicals formed. Glutathione, a tripeptide consisting of L-glutamate, L-cysteine and glycine, is one of the most well-known antioxidants in living tissues. Glutathione reacts with $\mathrm{H}_{2} \mathrm{O}_{2}$ and organic peroxides by catalyzing the glutathione peroxidase enzyme, an enzyme containing selenium in its active site, acting as an antioxidant and removing $\mathrm{H}_{2} \mathrm{O}_{2}$ from cells. Glutathione detoxifies hydrogen peroxide or organic oxides chemically and protects the cells from ROS damage. ${ }^{31}$ In our study, the TAS level was measured to investigate the inhibitory effect of cisplatin on antioxidant mechanisms. Our test results showed that there was a correlation between the decrease in tGSH and the TAS level. Niu et al. reported that cisplatin produced oxidative stress by decreasing GSH and TAS levels in liver tissue. ${ }^{29}$

Taxifolin used against cisplatin-induced oxidative liver damage significantly inhibited an increase in MDA and TOS levels, and decreased tGSH and TAS levels. It has been documented in previous studies that taxifolin reduced intracellular free radical levels, inhibited MDA and prevented the consumption of antioxidants. ${ }^{32}$ In another study, taxifolin was found to increase the effect of GSH. ${ }^{33}$ 
As noted above, taxifolin is a flavonoid. ${ }^{13}$ Previous studies have expressed that flavonoids demonstrate antioxidant activity by inhibiting lipid peroxidation and enzymatic reactions responsible for the formation of free radicals. ${ }^{34}$ In a recent study, it was suggested that taxifolin produces a hepatoprotective effect with antioxidant activity by inhibiting the lipid peroxidation pathway. ${ }^{35}$ Viewed in total, data from the reviewed literature are in agreement with our experimental results.

\section{Limitations}

In our study, it was necessary to investigate the effect of taxifolin on pro-inflammatory cytokine levels, known to play a role in the pathogenesis of cisplatin toxicity, in order to clarify its protective effect against hepatotoxicity caused by cisplatin. In addition, histopathological findings should support all biochemical findings. The small number of animals in the groups could be considered as another limitation.

\section{Conclusions}

As a result, cisplatin caused oxidative damage in the liver tissue of animals. In the CIS group, the oxidant-antioxidant balance deteriorated against the oxidants. Taxifolin prevented the increase in oxidants and decreased antioxidants in the liver tissue injured due to cisplatin. Taxifolin prevented the change in favor of oxidants in the oxidantantioxidant balance. These findings suggest that taxifolin could be a clinically beneficial agent for treating hepatotoxicity resulting from chemotherapy procedures.

\section{ORCID iDs}

Nezahat Kurt (1) https://orcid.org/0000-0002-1685-5332

Özge Nur Türkeri @

Bahadir Suleyman (1) https://orcid.org/0000-0001-5795-3177

Nuri Bakan (1) https://orcid.org/0000-0002-2139-7268

\section{References}

1. LebwohI D, Canetta R. Clinical development of platinum complexes in cancer therapy: A historical perspective and an update. Eur $J$ Cancer. 1998;34(10):1522-1534. doi:10.1016/s0959-8049(98)00224-x

2. Onk D, Mammadov R, Suleyman B, et al. The effect of thiamine and its metabolites on peripheral neuropathic pain induced by cisplatin in rats. Exp Anim. 2018;67(2):259-269. doi:10.1538/expanim.17-0090

3. Kuduban O, Kucur C, Sener E, Suleyman H, Akcay F. The role of thiamine pyrophosphate in prevention of cisplatin ototoxicity in an animal model. ScientificWorldJournal. 2013;2013:182694. doi:10.1155/ 2013/182694

4. Cao BB, Li D, Xing X, et al. Effect of cisplatin on the clock genes expression in the liver, heart and kidney. Biochem Biophys Res Commun. 2018;501(2):593-597. doi:10.1016/j.bbrc.2018.05.056

5. Bodiga VL, Bodiga S, Surampudi S, et al. Effect of vitamin supplementation on cisplatin-induced intestinal epithelial cell apoptosis in Wistar/NIN rats. Nutrition. 2012;28(5):572-580. doi:10.1016/j. nut.2011.09.007

6. Khan R, Khan AQ, Qamar W, et al. Chrysin abrogates cisplatin-induced oxidative stress, p53 expression, goblet cell disintegration and apoptotic responses in the jejunum of Wistar rats. Br J Nutr. 2012;108(9): 1574-1585. doi:10.1017/S0007114511007239
7. Liao Y, Lu X, Lu C, Li G, Jin Y, Tang H. Selection of agents for prevention of cisplatin induced hepatotoxicity. Pharmacol Res. 2008;57(2):125-131. doi:10.1016/j.phrs.2008.01.001

8. Tsang RY, AI-Fayea T, Au HJ. Cisplatin overdose: Toxicities and management. Drug Saf. 2009;32(12):1109-1122. doi:10.2165/11316640000000000-00000

9. Zheng $X N$, Wang $X W$, Li LY, et al. Pu-erh tea powder preventive effects on cisplatin-induced liver oxidative damage in Wistar rats. Asian Pac J Cancer Prev. 2014;15(17):7389-7394. doi:10.7314/apjcp. 2014.15.17.7389

10. Naqshbandi A, Khan W, Rizwan S, Khan F. Studies on the protective effect of flaxseed oil on cisplatin-induced hepatotoxicity. Hum Exp Toxicol. 2012;31(4):364-375. doi:10.1177/0960327111432502

11. Sun Y, Yang J, Wang LZ, Sun LR, Dong Q. Crocin attenuates cisplatininduced liver injury in the mice. Hum Exp Toxicol. 2014;33(8):855-862. doi:10.1177/0960327113511475

12. Mohamadi Yarijani Z, Godini A, Madani SH, Najafi H. Reduction of cisplatin-induced renal and hepatic side effects in rat through antioxidative and anti-inflammatory properties of Malva sylvestris L. extract. Biomed Pharmacother. 2018;106:1767-1774. doi:10.1016/j. biopha.2018.07.115

13. Wang $Q$, Wang $L, L i G, Y e$ B. A simple and sensitive method for determination of taxifolin on palladium nanoparticles supported poly (diallyldimethylammonium chloride) functionalized graphene modified electrode. Talanta. 2017;164:323-329. doi:10.1016/j.talanta.2016. 11.045

14. Topal F, Nar M, Gocer H, et al. Antioxidant activity of taxifolin: An activity-structure relationship. J Enzyme Inhib Med Chem. 2016;31(4): 674-683. doi:10.3109/14756366.2015.1057723

15. Manigandan K, Jayaraj RL, Jagatheesh K, Elangovan N. Taxifolin mitigates oxidative DNA damage in vitro and protects zebrafish (Danio rerio) embryos against cadmium toxicity. Environ Toxicol Pharmacol. 2015;39(3):1252-1261. doi:10.1016/j.etap.2015.04.021

16. Coskun R, Turan MI, Turan IS, Gulapolu M. The protective effect of thiamine pyrophosphate, but not thiamine, against cardiotoxicity induced with cisplatin in rats. Drug Chem Toxicol. 2014;37(3):290-294. doi:10.3109/01480545.2013.851688

17. Topal I, Bilgin OA, Çimen KF, et al. The effect of rutin on cisplatininduced oxidative cardiac damage in rats. Anatol J Cardiol. 2018;20(3): 136-142. doi:10.14744/AnatolJCardiol.2018.32708

18. Bradford MM. A rapid and sensitive method for the quantitation of microgram quantities of protein utilizing the principle of protein-dye binding. Anal Biochem. 1976;7(72):248-254. doi:10.1006/ abio.1976.9999

19. Ohkawa H, Ohishi N, Yagi K. Assay for lipid peroxides in animal tissues by thiobarbituric acid reaction. Anal Biochem. 1979;95(2):351-358. doi:10.1016/0003-2697(79)90738-3

20. Sedlak J, Lindsay RH. Estimation of total, protein-bound, and nonprotein sulfhydryl groups in tissue with Ellman's reagent. Anal Biochem. 1968;25(1):192-205. doi:10.1016/0003-2697(68)90092-4

21. Baker MA, Cerniglia GJ, Zaman A. Microtiter plate assay for the measurement of glutathione and glutathione disulfide in large numbers of biological samples. Anal Biochem. 1990;190(2):360-365. doi:10. 1016/0003-2697(90)90208-q

22. Erel O. A novel automated method to measure total antioxidant response against potent free radical reactions. Clin Biochem. 2004; 37(2):112-119. doi:10.1016/j.clinbiochem.2003.10.014

23. Erel O. A new automated colorimetric method for measuring total oxidant status. Clin Biochem. 2005;38(12):1103-1111. doi:10.1016/j.clinbiochem.2005.08.008

24. Palipoch S, Punsawad C. Biochemical and histological study of rat liver and kidney injury induced by cisplatin. J Toxicol Pathol. 2013; 26(3):293-299. doi:10.1293/tox.26.293

25. Icel E, Uçak T, Agcayazi B, et al. Effects of pycnogenol on cisplatininduced optic nerve injury: An experimental study. Cutan Ocul Toxicol. 2018;37(4):396-400. doi:10.1080/15569527.2018.1495224

26. Salman S, Kumbasar S, Gursan N, et al. Investigation of the relationship of some antihypertensive drugs with oxidant/antioxidant parameters and DNA damage on rat uterus tissue. Int J Fertil Steril. 2011;5(2):96-103. PMID:24963366

27. Goulart M, Batoréu MC, Rodrigues AS, Laires A, Rueff J. Lipoperoxidation products and thiol antioxidants in chromium-exposed workers. Mutagenesis. 2005;20(5):311-315. doi:10.1093/mutage/gei043 
28. Gutteridge JM. Lipid peroxidation and antioxidants as biomarkers of tissue damage. Clin Chem. 1995;41(12 Pt 2):1819-1828. PMID:7497639

29. Niu C, Ma M, Han X, Wang Z, Li H. Hyperin protects against cisplatin-induced liver injury in mice. Acta Cir Bras. 2017;32(8):633-640. doi:10.1590/s0102-865020170080000005

30. Eren H, Aydin HR, Tumkaya L, et al. Whortleberry protects kidney against the cisplatin-induced nephrotoxicity: An experimental study. Ren Fail. 2018;40(1):466-474. doi:10.1080/0886022X.2018.1500292

31. Murray RK, Granner DK, Mayes PA, Rodwell VW. Harper's Biochemistry. $25^{\text {th }}$ ed. New York, USA: McGraw-Hill Press; 2000.

32. Sun $\mathrm{X}$, Chen RC, Yang ZH, et al. Taxifolin prevents diabetic cardiomyopathy in vivo and in vitro by inhibition of oxidative stress and cell apoptosis. Food Chem Toxicol. 2014;63:221-232. doi:10.1016/j. fct.2013.11.013
33. Pereira RB, Sousa C, Costa A, Andrade PB, Valentao P. Glutathione and the antioxidant potential of binary mixtures with flavonoids: Synergisms and antagonisms. Molecules. 2013;18(8):8858-8872. doi:10. 3390/molecules 18088858

34. Cotelle N. Role of flavonoids in oxidative stress. Curr Top Med Chem. 2001;1(6):569-590. doi:10.2174/1568026013394750

35. Zhang $Y$, Jin $Q$, Li X, Jiang $M$, et al. Amelioration of alcoholic liver steatosis by dihydroquercetin through the modulation of AMPKdependent lipogenesis mediated by P2X7R-NLRP3-inflammasome activation. J Agric Food Chem. 2018;66(19):4862-4871. doi:10.1021/ acs.jafc.8b00944 